\title{
Subjective well-being: Mental health study among student in the Islamic boarding school
}

\author{
Lharasati Dewi, Fatwa Tentama, Ahmad Muhammad Diponegoro
}

Faculty of Psychology, Universitas Ahmad Dahlan, Indonesia

\begin{abstract}
Article Info
Article history:

Received Aug 6, 2020

Revised Dec 18, 2020

Accepted Jan 4, 2021

\section{Keywords:}

Family social support

Gratitude

Self-acceptance

Subjective well-being

ABSTRACT

The purpose of this study was to analyze the model of the influence of family social support, gratitude, and self-acceptance on subjective well-being in student in Islamic boarding schools. The population in this study was all student of class VII in boarding school $\mathrm{X}$ and boarding school $\mathrm{Y}$ in Yogyakarta, with a total of 430 students. The sample in this study was 150 students. The sampling technique used for this study was cluster random sampling. The data were collected by using several instruments in the form of scales. The scales consisted of family social support scale, gratitude scale, self-acceptance scale, and subjective well-being scale. Data analysis was performed by testing the outer model and the inner model. The data were analyzed using structural equation model (SEM) through the Smart Partial Least Square 3.2.8 program. The results of this study suggested that the formation of a model of the influence of family social support, gratitude, and self-acceptance on subjective well-being fits with empirical data obtained. In other words, there was a significant positive correlation between all variables being studied and subjective well-being. The theoretical model formed in this study was considered fit, so it can be used as a valid model reference in investigating adolescents' subjective well-being.
\end{abstract}

This is an open access article under the CC BY-SA license.

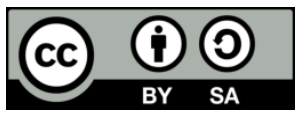

\section{Corresponding Author:}

Fatwa Tentama

Faculty of Psychology

Universitas Ahmad Dahlan

Pramuka Street No.42, Umbulharjo, Yogyakarta City, Indonesia

Email: fatwa.tentama@psy.uad.ac.id

\section{INTRODUCTION}

Happiness is a very important thing in life. Everyone wants happiness and tries to do whatever it takes to get it. The happiness that the individual feels in this case is called subjective well-being. Research on subjective well-being has shown varying but important results. Several studies suggest that subjective wellbeing can determine mental health [1], survival [2], developmental stages [3], and learning success [4, 5]. Given the importance of individual well-being, it is not surprising that it currently becomes the center of attention [6]. However, only a few studies have examined how subjective well-being develops in the adolescent stage [7-9]. Adolescence is the age of transition from childhood to adulthood, which is characterized by a need that must be met to cope with rapid physical changes, dramatic psychological changes, and transitions in social and cultural contexts [10]. Therefore, adolescents need to achieve subjective well-being [11, 12] for the learning process, adapting to the community, and improving quality of life [13].

Adolescent perceptions of the education system are more related to feelings of dissatisfaction, such as stress and pressure [14-18]. Subjective well-being that focuses on adolescents is increasingly preferred to be studied, especially in Indonesia [19-22]. Subjective well-being is a broad picture that refers to all forms of 
evaluation of one's life or emotional experience, including life satisfaction, positive affect, and negative affect $[23,24]$. Subjective well-being can be achieved when individuals see themselves as having a pleasant, satisfying, and quality life so that they feel positive feelings [25]. Subjective well-being is a measure of an individual's quality of life [26].

The benefits generated by subjective well-being will lead to physical and psychological health [27-30], including reducing the risk of stroke [27, 31] and arousing enthusiasm [32]. This is also in line with the study conducted by Wiest, et al. [30], which suggests that life satisfaction and positive feelings can prevent someone from being ill. Meanwhile, the impact of poor subjective well-being on a person, among others, is the emergence of anxiety, making an individual have low coping and low motivation. Other impacts that arise from poor well-being are vulnerability to depression and stress [7]. This is reinforced by Santrock [33], who illustrates that adolescents have very unstable affective conditions, which cause problems such as difficulty adapting to the social environment, the emergence of affective problems, and the emergence of health problems [34]. Someone who feels a lot of negative emotions is more at risk of cancer [35]. Not only that, but depressed teens are also more likely to be overweight and not healthy [36].

The problems faced by adolescents are very diverse, and subsequently, the problem solving required is different from one another, which ultimately affects the level of subjective well-being. Several factors can affect the level of subjective well-being, and one of which is family social support. The results showed a positive relationship between subjective well-being and family social support $[37,38]$. This means that social support can predict subjective well-being, and social support can also be beneficial for one's subjective wellbeing. According to Sarafino, et al. [39], social support is a way to show care, affection, and appreciation for others. Social support is a kind of information and feedback from others, indicating love, caring, and respect. It will also enable someone to get involved in mutual communication [40].

Individuals who receive social support will feel valued, loved, and respected. They will also become part of a group that can assist when other people need help. The existence of social support from the family and other people around such as peers in boarding schools context will make someone feel comfortable to study in boarding schools. Without social support, especially from the family, someone will feel ignored, and that will make it difficult for them to stay in the boarding school. Social support is needed to reduce the negative impacts arising from these conditions. Thus, perceived social support can explain an individual's life satisfaction and positive affect. Yu [41] explained that there was a significant relationship between social support and subjective well-being. This is also supported by the research of Tomás, et al. [42], which suggest that family social support has a strong influence on the subjective well-being of adolescents.

Besides social support, other factors influence subjective well-being, namely gratitude. Several studies have shown that there is a positive relationship between subjective well-being and gratitude [43, 44]. Gratitude is defined as part of a broader life orientation through appreciation for positive things in the world [45]. Gratitude is a feeling in human relationships when someone acknowledges valuable supports, benefits, and goodness that they receive from others [46]. This is in line with Bono, et al., [47], who said that gratitude is a feeling experienced by someone when getting a gift or benefit from others.

The results of the interview indicated a feeling of dissatisfaction from the student because they could not maximally exert their abilities and did the things they wanted. There was a need for gratitude to feel satisfied living in the Islamic boarding school, which could increase subjective well-being. This is reinforced by research conducted by Robustelli [44], which shows a positive relationship between gratitude and subjective well-being, namely the component of life satisfaction in the domain of social relations, employment, and health and global life satisfaction in the United States and Japan. Gratitude is an important factor to increase subjective well-being.

In addition to family social support and gratitude, self-acceptance also plays an important role in the formation of student' subjective well-being. The study results show a positive relationship between subjective well-being and self-acceptance [48, 49]. Someone with good self-acceptance will be able to control their emotions because they can accept themselves as who they are. Low self-acceptance can be overcome if a person can accept himself by acknowledging and accepting all the weaknesses and strengths that he/she has [50].

This research shows that self-acceptance is very important to help student to feel satisfied in life, more positive emotions, and to be able to control negative emotions so that they can achieve subjective wellbeing. Research conducted by Nayana [51] explains that a person with an unstable condition can still feel comfortable as long as he/she has good self-acceptance with his environment. Self-acceptance is an important factor that influences subjective well-being [52].

This study offers novelty because it tries to reveal the formation of the influence model between family social support, gratitude, self-acceptance, and subjective well-being. There were very little, if any, previous studies that simultaneously tested these variables. Second, the data analysis technique used in this research is structural equation model (SEM) through the Smart Partial Least Square 3.2.8 program, whereas 
previous studies that examined subjective well-being mainly use data analysis such as Lisrel, AMOS or SPSS. This study uses partial least square (PLS) because it aims to design a new model and then test the model. Model design and model testing can only be done using PLS. The three participants in this study were typical, namely adolescents student in Islamic boarding schools, which differed from subjects in previous studies.

\section{RESEARCH METHOD}

\subsection{Population, sample, and sampling technique}

The population in this study are all male and female student (students) in class VII who are currently attending boarding school X and boarding school Y in Bantul Regency Yogyakarta, totaling 430 student. The sample in this study consists of 150 student from both schools. The sampling technique used in this study is cluster random sampling.

\subsection{Research instrument}

The instrument used to measure subjective well-being was a scale that researchers arranged based on two subjective well-being components proposed by Diener [23], namely the cognitive component (life satisfaction) and the affective component (positive affect and negative affect). The scale consisted of 40 items in which each component had 20 items. The response from this scale was strongly agreed (SA), agree (A), disagree (DA), and strongly disagree (SDA). Examples of items from this scale are "Establishing good relationships with boarding school caretakers", "Enjoying life in the boarding school", and "The family supports me to study in the boarding school".

The researchers also designed a scale to measure family social support. This scale was arranged based on four aspects of family social support from Sarafino [39] consisting of aspects of emotional support, appreciation support, instrumental support, and information support. Each component of this scale had six items, so there were 24 items in total. The response of this scale is very appropriate (VA), appropriate (A), not appropriate (NA), and very inappropriate (VIN). Examples of items from this scale are "My parents advised me to complete my assignments well," "My parents bought school supplies such as books and the Qur'an to support my school while in boarding schools" and "My parents gave praise for the grades of Qur'an memorization that I got".

The instrument used to measure gratitude was also a scale that researchers arranged based on three aspects of gratitude from Watkins [53], namely a sense of abundance, appreciation of the contribution of others, and simple pleasures appreciation. The scale consisted of 18 items in total, and each aspect had six items. The response of this scale is very appropriate, appropriate, not appropriate, and very inappropriate. Examples of items on this scale are "I thank God because I go to this boarding school", "I am nothing without my parents' prayer," and "I believe the health that I have now is gifts from God".

Similarly, the instrument used to measure self-acceptance was a scale that researchers arranged based on three aspects of self-acceptance from Carson and Langer [54], namely one's ability and willingness to let others see their true self, proper self-evaluation, and decision making. The total items of this scale were 18 items, with each aspect consisted of six items. The response of this instrument is very appropriate (VA), appropriate (A), not appropriate (NA), and very inappropriate (VIN). Examples of the statements from this scale are "I try to be myself", "I take full responsibility for my life choices", and "I accept any criticism from others".

\subsection{Construct validity and reliability}

The stage of testing the construct validity and reliability is called the evaluation of the measurement model or outer model. Hair, et al., [55] explain the construct validity as the extent to which a measuring instrument is able to measure the construct that is to be measured. The construct validity test consists of convergent validity and discriminant validity. Convergent validity is based on the loading factor value used to express the validity of a construct, and a construct is said to be valid if it has the loading factor value of $>0.4$ [56] and average variance extracted (AVE) value of $>0.5$ [57]. Discriminant validity test can be done by comparing the value of the root of average variance extracted (AVE) in each construct with the correlation between constructs in the model. Whereas the construct reliability test was conducted to show the internal consistency of the measuring instrument. Construct reliability testing includes composite reliability and Cronbach alpha. The expected criteria for composite reliability and Cronbach's alpha value are $>0.7$ [58].

\subsection{Data analysis}

The data collected in the present study were analyzed using the SmartPLS 3.2.8 program, which included testing the outer model and inner model. Data analysis using smartPLS can be used to design or test models, and further explain the presence or absence of influence between exogenous variables and 
endogenous variables [59]. The stages of forming and testing the model used in this study include the R-squares test, the predictive relevance test (Q2), the goodness of fit (GoF), and the index test [60].

\section{RESULTS AND DISCUSSION}

The SmartPLS 3.2.8 program was employed to test the outer model and the inner model, and the result as shown in Figure 1.

\subsection{Outer model test}

The outer model analysis includes convergent validity, discriminant validity, composite reliability, and Cronbach alpha. The outer model test results as shwon in Figure 1.

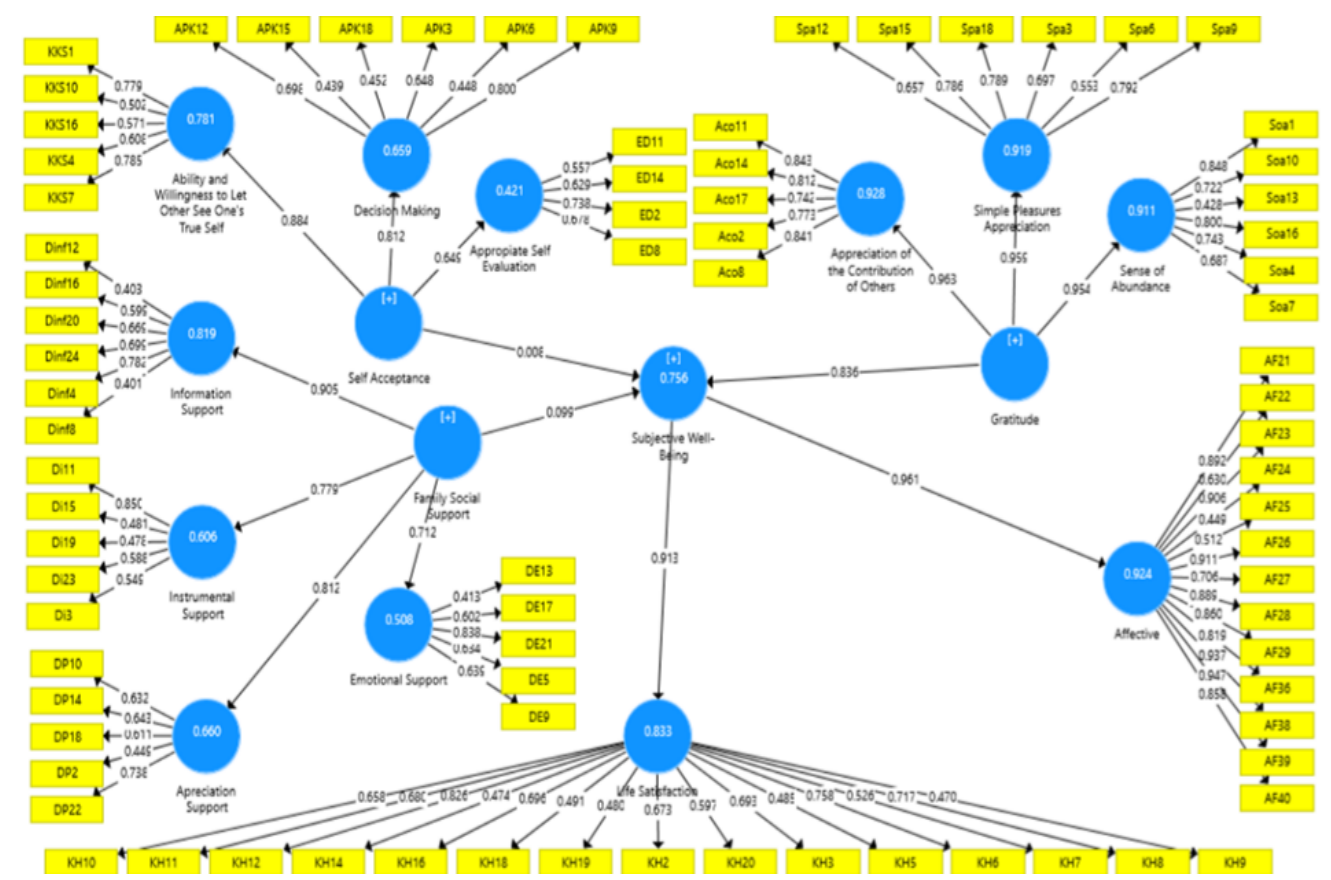

Figure 1. Outer model test results

\subsubsection{Convergent validity test}

Convergent validity is generated based on the loading factor values used to express the validity of a construct, and it should be $>0.4$. In addition, a valid construct should also meet the average variance extracted (AVE) values of $>0.5$. Based on the results of data analysis, it shows the loading factor for each item meets the criteria of $>0.4$, so each item is valid. The subjective well-being scale consists of 40 items, and there were only 28 valid items. In the family social support scale, there were 21 valid items. Meanwhile, there were 17 valid items obtained from the gratitude scale. Finally, the self-acceptance had 15 valid items.

In terms of the root value of average variance extracted (AVE), each variable also meets the discriminant validity criteria (AVE $>0.5$ ). The average variance extracted value (AVE) for each variable can be seen in Table 1. Based on Table 1 above, all of the variables have an average variance extracted value (AVE) $>0.5$, so that it can be concluded that all research variables have met the requirements of convergent validity. Based on Table 2 above, all of the variables have an average variance extracted value (AVE) $>0.5$, so that it can be concluded that all research variables have met the requirements of convergent validity.

Table 1. The root value of average variance extracted (AVE)

\begin{tabular}{ccccc}
\hline & Subjective well-being & Family social support & Gratitude & Self-acceptance \\
\hline Subjective well-being & $\mathbf{0 . 7 6 6}$ & 0.339 & 0.863 & 0.078 \\
Family social support & 0.339 & $\mathbf{0 . 7 1 5}$ & 0.283 & 0.462 \\
Gratitude & 0.863 & 0.283 & $\mathbf{0 . 7 2 0}$ & 0.029 \\
Self-acceptance & 0.782 & 0.462 & 0.029 & $\mathbf{0 . 7 8 4}$ \\
\hline
\end{tabular}


Table 2. Average variance extracted (AVE)

\begin{tabular}{ccc}
\hline Variable & Average variance extracted (AVE) & Explanation \\
\hline Subjective well-being & 0.586 & Valid \\
Family social support & 0.518 & Valid \\
Gratitude & 0.518 & Valid \\
Self-acceptance & 0.614 & Valid \\
\hline
\end{tabular}

\subsubsection{Discriminant validity test}

Discriminant validity can be seen by comparing the root values of average variance extracted (AVE) between variables. A scale is valid if the AVE root correlation value of each variable is higher than (AVE) root correlation value with other variables [56]. The root value of average variance extracted (AVE) can be seen in Table 1. The table above suggests that all variables have met the criteria in which the comparison of the same variable correlation is greater than the correlation between each construct of the variable. Thus, it can be concluded that all variables in this study have met the discriminant validity requirements.

\subsubsection{Reliability}

Construct reliability can be seen from the composite reliability and Cronbach alpha values. A construct is said to be reliable if the composite reliability and Cronbach alpha value are $>0.7$, and 0.6 values are still acceptable [56]. In addition, according to Cooper, the root value of average variance extracted (AVE), which is $>0.5$, has further supported reliability because by fulfilling the construct validity, the valid construct is a reliable construct [58]. The composite reliability and Cronbach values in this study are shown in Table 3. The table shows that all variables have meet the criteria of composite reliability of $>0.7$ and Cronbach's alpha value of $>0.6$. Thus, it can be said that all constructs or variables in this study have met the construct reliability requirements

Table 3. Construct reliability

\begin{tabular}{cccc}
\hline Variable & Composite reliability & Cronbach alpha & Explanation \\
\hline Subjective well-being & 0.920 & 0.933 & Reliable \\
Family social support & 0.808 & 0.862 & Reliable \\
Gratitude & 0.933 & 0.943 & Reliable \\
Self-acceptance & 0.687 & 0.827 & Reliable \\
\hline
\end{tabular}

\subsection{Inner model test}

The inner model test aims to ensure that structural models that have been previously built are robust and accurate. The results of the inner model test can be seen in Table 4 and Figure 2. Inner model test aims to ensure that structural models that have been previously built are robust and accurate. The results of the inner model test are shown in Table 5 and Figure 2.

\subsubsection{Hypothesis test}

After the model is formed and declared fit, it can be continued by looking at the influence between variables. Hypothesis testing is done by looking at the probability value (p-value) in which the value of $p$ has to be $<0.05$. Looking at the value of $t$-statistics of $>1.96$ is also required because it indicates that the hypothesis is accepted. The following analysis result of the p-values and t-statistics values are shown in Table 5.

Table 4. Analysis result of R-Square, Q2, and GoF

\begin{tabular}{|c|c|c|c|}
\hline Criteria & Rule of thumb & Value & Explanation \\
\hline $\begin{array}{c}\text { Coefficient } \\
\text { determinant }\left(\mathrm{R}^{2}\right)\end{array}$ & 0.67 (strong), 0.33 (moderate), dan 0.19 (weak) & 0.755 & $\begin{array}{l}\text { Strong effect of exogenous variables } \\
\text { on endogenous variables. }\end{array}$ \\
\hline $\begin{array}{l}\text { Predictive relevance } \\
\qquad\left(\mathrm{Q}^{2}\right)\end{array}$ & $\begin{array}{l}\mathrm{Q}^{2 \text { value }}>0 \text { (good predictive model) } \\
\mathrm{Q}^{2 \text { value }}<0 \text { (poor predictive relevance) }\end{array}$ & 0.411 & Good predictive relevance \\
\hline Goodness of Fit (GoF) & $\begin{array}{l}\text { GoF value criteria of } 0.1 \text { (weak GoF), } 0.25 \text { (moderate } \\
\text { GoF) and } 0.36 \text { (strong GoF) }\end{array}$ & 0.647 & Goodness of Fit (GoF) strong \\
\hline
\end{tabular}

Table 5. Hypothesis test

\begin{tabular}{cccccc}
\hline Variable influence & P-values & T-Statistics & Original sample & Criterion & Explanation \\
\hline $\begin{array}{c}\text { Family social support-subjective } \\
\text { well-being }\end{array}$ & 0.029 & 2.015 & 0.099 & $\mathrm{P}<0.05$ & $\begin{array}{c}\text { There is a positive and very } \\
\text { significant influence }\end{array}$ \\
$\begin{array}{c}\text { Gratitude-subjective well-being } \\
\begin{array}{c}\text { Self-acceptance-subjective well- } \\
\text { being }\end{array}\end{array}$ & 0.000 & 32.13 & 0.836 & $\mathrm{P}<0.05$ & $\begin{array}{c}\text { There is a positive and very } \\
\text { significant influence }\end{array}$ \\
There is no significant influence \\
\hline
\end{tabular}

Int. J. Public Health Sci. Vol. 10, No. 1, March 2021: 146-158 


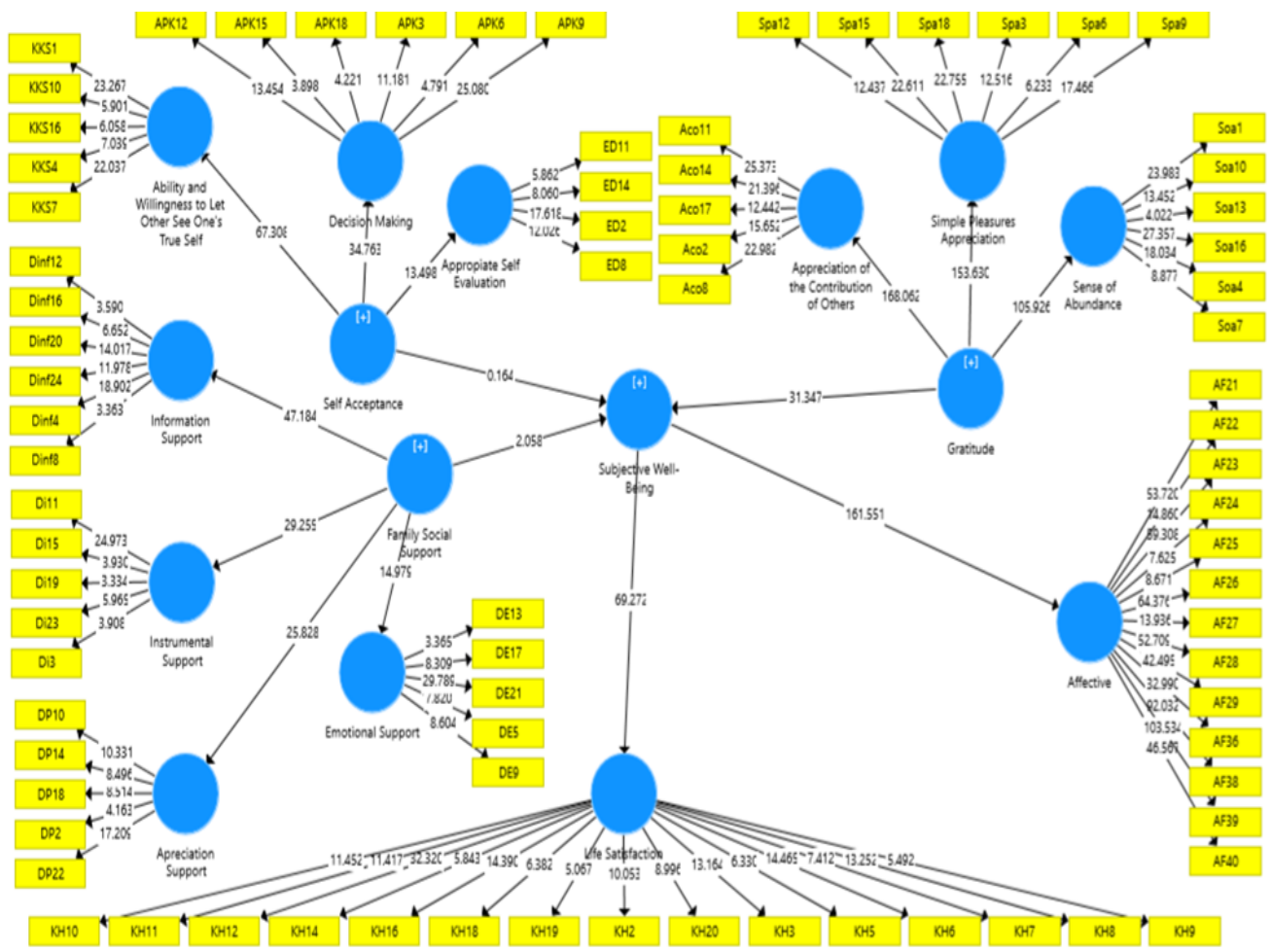

Figure 2. Inner model test result

\section{DISCUSSION}

The notion of subjective well-being was first proposed by Diener [25] and is now widely accepted by various researchers [61-63]. Along with the development of positive psychology, subjective well-being has become one of the important constructs in the world of education [64-66]. Some literature that is in line with the present study which has examined subjective well-being in the school environment include Long, et al., [67], Tian, et al. [68], Tian, et al. [69], Tian, et al. [70], Tian, et al. [71], Tomyn, et al. [63]. Schools have the potential to give students the opportunity to develop cognitive and social capacities, and subjective wellbeing investigated in this study is an important index to measure mental health and quality of life of students [72]. Factors that influence subjective well-being are classified into subjective and objective categories [73]. Subjective factors include personality characteristics, such as self-concept [74], self-acceptance [75], gratitude [53]. Meanwhile, objective factors include social relations [24], family support [76], and a positive social environment [77].

The analysis results suggest that first hypothesis is accepted because it fulfills several set of requirements, including the coefficient of determination (R2), predictive relevance (Q2), and goodness of fit index $(\mathrm{GoF})$. It can be said that the model which describes the influence of family social support, gratitude, and self-acceptance to subjective well-being in boarding school student fit with empirical data obtained from the data. Thus, this research offers the novelty in the form of the formation of models of the influence of family social support, gratitude, self-acceptance to subjective well-being. There were very little, if any, previous studies that simultaneously tested these particular variable models. Models of previous research results such as those produced by Zhang, et al. [78] are models of the influence of attribute style and optimism on subjective well-being. Meanwhile, Bajaj, et al. [79] produce resilience models in mediating the influence of attention on subjective well-being. Sánchez-Álvarez, et al. on the other hand, [80] produce a model of the influence of meta-mood traits on subjective well-being in students. Finally, Agarwal, et al. [81] have created a model of a reciprocal relationship between the quality of work-life and subjective well-being.

Secondly, this research also has novelty mainly because it uses structural equation model (SEM) through the Smart Partial Least Square 3.2.8 program as the data analysis technique whereas previous studies have extensively used structural equation modeling (SEM) with the help of the AMOS program in compiling subjective well-being literature [82, 83]. Meanwhile, Pi, Lin, et al. [84] and Siedlecki, et al. [38] examine subjective well-being with the help of LISREL. Finally, the study participants also become a potential source of novelty because Islamic boarding school arguably hasn't become the focus of investigation in previous research. 
The second hypothesis in this study was also accepted, showing a positive and significant influence between family social support on subjective well-being. So far, the literature on the influence of family social support on subjective well-being has been carried out in a variety of different settings, both in the social sphere [85], development context [38], organizations [86], education context [87], to cross-cultural research context [88]. The present study focuses on the scope of education in Islamic boarding schools, where the family is an important factor in social activities involving parents and teachers; thus, social support activities between parents, teachers, and students are the main social relations [89]. Support and assistance offered by families can increase the subjective well-being of students [90]. Support as a first step to developing positive interactions and communication between family members [91]. The creation of positive communication will produce a range of benefits that lead to the mental health of students and families [92].

Children in Islamic boarding schools do not live with relatives, but they live with friends, supervisors, teachers, principals, and caregivers so that all of these parties become the main actor who will build and maintain interpersonal relationships with the student. They also become the main source of social support $[93,94]$. The social support referred here is the students' perceptions about general support and supporting behavior from their social networks $[95,96]$. The family's social support is very important for students because it can improve students' capacity to play a social role, and it can further protect students from harmful things [97]. During adolescence, the need for social support from peers, boarding supervisors, and teachers will increase [98]. Individuals tend to receive more support from peers and teachers than parents in this case [99, 100]. Students' cognitive development depends heavily on family support within the boarding school context, which has started from elementary to high school [101]. During this transition, a positive relationship with the family has a profound impact on the overall satisfaction of boarding students' life $[102,103]$.

The third hypothesis in this study was also accepted. It shows a positive and very significant influence between gratitude and subjective well-being. So far, gratitude has been one of the variables which receive the lowest attention [104, 105], but historically, gratitude is considered important for the functioning of life [106-108]. Much evidence emerges stating that gratitude is closely related to all aspects of well-being [109-113]. Gratitude is an emotion that occurs after students receive the assistance that is considered valuable or important for their lives $[114,115]$. Gratitude is emotion is always directed to appreciate the beneficial actions committed by others including a very simple action, and this attitude can increase life satisfaction [114, 116].

Gratitude is part of a broader life orientation that pays attention and values positive things in the world [114, 117]. Gratitude serves as an indicator of aspects of life that must be respected [105, 118]. It neutralizes negative emotions, so students tend not to get angry easily when facing conflicts or social problems $[119,120]$. The contribution of gratitude in improving individual well-being is to foster emotional warmth, to seek social activities, and to always think positively [121, 122]. Students who are grateful have a higher openness to feelings, ideas, and positive values, and this is related to the concept of humanistic wellbeing $[123,124]$. It further enhances the image of life. Gratitude is strongly associated with mood and life satisfaction [122, 125]. Students with grateful personalities tend to avoid excessive stress that leads to depression and disorders [115, 126, 127].

The fourth hypothesis in this study, on the other hand, was rejected. It shows that self-acceptance has no significant influence on subjective well-being. Some previous research results contradict the results of this study, which show that there is a positive relationship between self-acceptance and subjective well-being [75, 128-130]. Self-acceptance is an important indicator of mental health [54]. This concept involves the acceptance of unpleasant experiences in the past, present, and future [131, 132]. Self-acceptance to others reflects the attitude of individuals towards themselves and others [133]. Students with selfacceptance will be able to accept their condition. They will not blame or criticize his thoughts, feelings, and emotions [134]. Self-acceptance helps individuals to pay attention to what is happening in the present. In this way, students do not easily judge the opinions of others [135]. The result of the present study shows that selfacceptance is not related to the levels of self-welfare, and this result subsequently refuted what researchers have documented previously. This study, therefore, has its novelty as it shows that self-acceptance does not contribute to life satisfaction.

Previous studies suggest that students who cannot accept their condition might still have better subjective well-being as long as they receive sufficient support or attention [136, 137]. Students in their adolescence tend to need self-recognition [33, 138]. A series of social activities and roles are played by students to attract the attention of the surrounding environment [139]. This concept underlies that recognition and attention factors are priorities that must be met so that self-acceptance factors are ignored [140]. Low self-acceptance does not always have an impact on individual life satisfaction [141, 142]. Some student admitted that even though living in boarding schools had many limitations, they still felt comfortable because, in this environment, positive family ties were formed. They remind each other in terms of kindness and when behaving wrongly, motivating each other to increase morale and mutual support when there are

Int. J. Public Health Sci. Vol. 10, No. 1, March 2021: 146 - 158 
student who are uncomfortable being away from home. This form of attention is a source of satisfaction and welfare for student, so student can have subjective well-being even though their self-acceptance is low.

\section{CONCLUSION}

Based on the results of the research analysis, it is known that the subjective well-being model fits with empirical data. The results of the model illustrate the influence of family social support, gratitude, selfacceptance to subjective well-being of student in Islamic boarding school. In addition, there is a positive and significant influence between family social support on subjective well-being with a contribution of $9.9 \%$. Similarly, gratitude is also shown to have a significant contribution to wellbeing with a contribution of 83.6\%. However, results also show that there is no correlation between self-acceptance and subjective wellbeing. Thus, the model in this study can be used to develop and handle subjective well-being, both theoretically and practically, especially in adolescent student.

\section{ACKNOWLEDGEMENTS}

The authors wish to thank the Ministry of Research and Technology/National Research and Innovation Agency, Republic of Indonesia (RISTEK-BRIN) for providing support and funding for the completion of this research.

\section{REFERENCES}

[1] L. Bolier, M. Haverman, G. Westerhof, H. Riper, et al., "Positive psychology interventions: A meta-analysis of randomized controlled studies," BMC Public Health, vol. 13, no. 1, pp. 119-139, 2013, doi: https://doi.org/10.1186/1471-2458-13-119.

[2] S. Lamers, L. Bolier, G. Westerhof, et al., "The impact of emotional well-being on long-term recovery and survival in physical illness: A meta-analysis," Journal of Behavioral Medicine, vol. 35, no. 5, pp. 538-547, 2012, doi: https://doi.org/10.1007/s10865-011-9379-8.

[3] R. Howell, M. Kern, and S. Lyubomirsky, "Health benefits: Meta-analytically determining the impact of well-being on objective health outcomes," Health Psychology Review, vol. 1, no. 1, pp. 83-136, 2007, doi: https://doi.org/10.1080/17437190701492486.

[4] S. Lyubomirsky, L. King, and E. Diener, "The benefits of frequent positive affect: Does happiness lead to success?," Psychological Bulletin, vol. 131, no. 6, pp. 803-855, 2005, doi: https://doi.org/10.1037/00332909.131.6.803.

[5] E. Diener, S. Pressman, J. Hunter, and D. Delgadillo-Chase, "If, why, and when subjective well-being influences health, and future needed research," Applied Psychology: Health and Well-Being, vol. 9, no. 2, pp. 133-167, 2017, doi: https://doi.org/10.1111/aphw.12090.

[6] I. Peña-López, "PISA 2015 results (volume III): Students' well-being, OECD," 2017. [Online]. Available: doi: https://dx.doi.org/10.1787/9789264273856-en.

[7] N. Park, "The role of subjective well-being in positive youth development," The Annals of the American Academy of Political and Social Science, vol. 591, no. 1, pp. 25-39, 2004, doi: https://doi.org/10.1177/0002716203260078.

[8] K. Salmela-Aro and H. Tuominen-Soini, "Adolescents' life satisfaction during the transition to post-comprehensive education: Antecedents and consequences," Journal of Happiness Studies, vol. 11, no. 6, pp. 683-701, 2010, doi: https://doi.org/10.1007/s10902-009-9156-3.

[9] D. Shek and T. Liu, "Life satisfaction in junior secondary school students in Hong Kong: A 3-year longitudinal study," Social Indicators Research, vol. 117, no. 3, pp. 777-794, 2014, doi: https://doi.org/10.1007/s11205-0130398-4.

[10] T. Gelhaar, I. Seiffge-Krenke, A. Borge, et al., "Adolescent coping with everyday stressors: A seven-nation study of youth from Central, Eastern, Southern, and Northern Europe," European Journal of Developmental Psychology, vol. 4, no. 2, pp. 129-156, 2007, doi: https://doi.org/10.1080/17405620600831564.

[11] D. Balk, D. Zaengle, and C. Corr, "Strengthening grief support for adolescents coping with a peer's death," School Psychology International, vol. 32, no. 2, pp. 144-162, 2011, doi: https://doi.org/10.1177/0143034311400826.

[12] J. Coleman and A. Hagell, "Adolescence, Risk and Resilience: Against the Odds," Chicester: Wiley, 2007.

[13] B. Fredrickson, "Positivity," New York: Crown, 2009.

[14] F. Casas, S. Bălţătescu, I. Bertran, M. González, et al., "School satisfaction among adolescents: Testing different indicators for its measurement and its relationship with overall life satisfaction and subjective well-being in Romania and Spain," Social Indicators Research, vol. 111, no. 3, pp. 665-681, 2012, doi: https://doi.org/10.1007/s11205012-0025-9.

[15] T. Dinisman, C. Montserrat, and F. Casas, "The subjective well-being of Spanish adolescents: Variations according to different living arrangements," Children and Youth Services Review, vol. 34, no. 12, pp. 2374-2380, 2012, doi: https://doi.org/10.1016/j.childyouth.2012.09.005.

[16] G. Rees, H. Goswami, L. Pople, et al., "The Good Childhood Report," The Children's Society and University of York, 2012. 
[17] D. Navarro, C. Montserrat, S. Malo, et al., "Subjective well-being: What do adolescents say?," Child and Family Social Work, vol. 22, no. 1, pp. 175-184, 2017, doi: https://doi.org/10.1111/cfs.12215.

[18] M. González-Carrasco, S. Malo, F. Casas, et al., "The assessment of subjective well-being in young children: Strengths and challenges," Journal of Social Research \& Policy, vol. 6, no. 2, pp. 71-81, 2015.

[19] L. Camfield, N. Streuli, and M. Woodhead, "What's the use of 'Wellbeing' in contexts of child poverty? Approaches to research, monitoring and children's participation," The International Journal of Human Rights, vol. 17, no. 1, pp. 65-109, 2009, doi: https://doi.org/10.1163/157181808X357330.

[20] D. Navarro, "Adolescent social participation in the school context: A psychosocial study of a participatory experience [In Katala La participació social dels adolescents en el context escolar: Estudi psicosocial d'una experiència participative]," Thesis, University of Girona, Girona, 2011.

[21] S. Malo, D. Navarro, and F. Casas, "The use of audiovisual media in adolescence and its relationship with subjective well-being: Qualitative analysis from an intergenerational and gender perspective [In Spain El uso de los medios audiovisuales en la adolescencia y su relación con el bienestar subjetivo: Análisis cualitativo desde la perspectiva intergeneracional y de género]," Athenea Digital, vol. 12, no. 3, pp. 27-49, 2012.

[22] L. Coombes, J. Appleton, D. Allen, and P. Yerrell, "Emotional health and well-being in schools: Involving young people," Children and Society, vol. 27, no. 3, pp. 220-232, 2011, doi: https://doi.org/10.1111/j.1099-0860.2011.00401.x.

[23] E. Diener, "Positive psychology: past, present, and future," In Oxford Handbook of Positive Psychology, New York: Oxford University Press, 2009

[24] E. Diener, L. Tay, and S. Oishi, "Rising income and the subjective well-being of nations," Journal of Personality and Social Psychology, vol. 104, no. 2, pp. 267-276, 2013, doi: https://doi.org/10.1037/a0030487.

[25] E. Diener, "Assessing subjective well-being: Progress and opportunities," Social Indicators Research, vol. 31, no. 2, pp. 103-157, 1994, doi: https://doi.org/10.1007/BF01207052.

[26] P. Dolan, T. Peasgood, and M. White, "Do we really know what makes us happy? A review of the economic literature on the factors associated with subjective wellbeing," Journal of Economic Psychology, vol. 29, no. 1, pp. 94-122, 2008, doi: https://doi.org/10.1016/j.joep.2007.09.001.

[27] D. Blanch flower, A. Oswald, and S. Stewart-Brown, "Is psychological well-being linked to the consumption of fruit and vegetables?" Social Indicators Research, vol. 114, no. 3, pp. 785-801, 2013, doi: https://doi.org/10.1007/s11205012-0173-y.

[28] E. Diener and M. Chan, "Happy people live longer: Subjective well-being contributes to health and longevity," Applied Psychology: Health and Well-Being, vol. 3, no. 1, pp. 1-43, doi: https://doi.org/10.1111/j.17580854.2010.01045.x.

[29] A. Ong, "Pathways linking positive emotion and health in later life," Current Directions in Psychological Science, vol. 19, no. 6, pp. 358-362, 2010, doi: https://doi.org/10.1177/0963721410388805.

[30] M. Wiest, B. Schüz, N. Webster, et al., "Subjective well-being and mortality revisited: Differential effects of cognitive and emotional facets of well-being on mortality," Health Psychology, vol. 30, no. 6, pp. 728-735, 2011, doi: https://doi.org/10.1037/a0023839.

[31] K. Davidson, E. Mostofsky, and W. Whang, "Don't worry, be happy: positive affect and reduced 10-year incident coronary heart disease: The Canadian Nova Scotia Health Survey," European Heart Journal, vol. 31, no. 9, pp. 1065-1070, 2010, doi: https://doi.org/10.1093/eurheartj/ehp603.

[32] S. Pressman and S. Cohen, "Positive emotion word use and longevity in famous deceased psychologists," Health Psychology, vol. 31, no. 3, pp. 297-305, 2012, doi: https://doi.org/10.1037/a0025339.

[33] J. Santrock, "Life-span development," McGraw-Hill, 2007.

[34] S. Leontopoulou and S. Triliva, "Explorations of subjective wellbeing and character strengths among a Greek University student sample," International Journal of Wellbeing, vol. 2, no. 3, pp. 251-270, 2012, doi: https://doi.org/10.5502/ijw.v2.i3.6.

[35] T. Russ. E. Stamatakis, M. Hamer, et al., "Association between psychological distress and mortality: Individual participant pooled analysis of 10 prospective cohort studies," British Medical Journal, pp. 1-14, 2012, doi: https://doi.org/10.1136/bmj.e4933.

[36] L. Kubzansky, M. Gilthorpe, and E. Goodman, "A prospective study of psychological distress and weight status in adolescents/young adults," Annals of Behavioral Medicine, vol. 43, no. 2, pp. 219-228, 2012, doi: https://doi.org/10.1007/s12160-011-9323-8.

[37] F. Lu and Y. Hsu, "Injured athletes' rehabilitation beliefs and subjective well-being: The contribution of hope and social support," Journal of Athletic Training, vol. 48, no. 1, pp. 92-98, 2013, doi: https://doi.org/10.4085/1062-6050-48.1.03.

[38] K. Siedlecki, T. Salthouse, S. Oishi, et al., "The relationship between social support and subjective well-being across age," Social Indicators Research, vol. 117, no. 2, pp. 561-576, 2014, doi: https://doi.org/10.1007/s11205013-0361-4.

[39] E. Sarafino and T. Smith, "Health Psychology," Wiley, 2014.

[40] L. King, "General Psychology: An Appreciative View [in Indonesian],” Salemba Humanika, 2012.

[41] B. Li, F. Yu, and Z. Zhou, "Positive psychological capital: A new approach to social support and subjective wellbeing," Social Behavior and Personality, vol. 42, no. 1, pp. 135-144, 2014, doi: https://doi.org/10.2224/sbp.2014.42.1.135.

[42] J. Tomás, M. Gutiérrez, A. Pastor, et al., "Perceived social support, school adaptation and adolescents' subjective wellbeing," Child Indicators Research, pp. 1-21, 2020, doi: https://doi.org/10.1007/s12187-020-09717-9.

[43] J. Froh, C. Yurkewicz, and T. Kashdan, "Gratitude and subjective well-being in early adolescence: Examining gender differences," Journal of Adolescence, vol. 32, pp. 633-650, 2009, doi: https://doi.org/10.1016/j.adolescence.2008.06.006. 
[44] B. Robustelli and M. Whisman, "Gratitude and life satisfaction in the United States and Japan," Journal of Happiness Studies, vol. 19, no. 1, pp. 41-55, 2016, doi: https://doi.org/10.1007/s10902-016-9802-5.

[45] A. Wood, J. Froh, and A. Geraghty, "Gratitude and well-being: A Review and Theoretical Integration," Clinical Psychology Review, vol. 30, no. 7, pp. 890-905, 2010, doi: https://doi.org/10.1016/j.cpr.2010.03.005.

[46] T. Lomas, J. Froh, R. Emmons, et al., "Gratitude interventions: A review and future agenda," In The Wiley Blackwell Handbook of Positive Psychological Interventions, A. Parks and S. Schueller, Eds. John Wiley \& Sons, 2014.

[47] G. Bono, M. Krakauer, and J. Froh, "The power and practice of gratitude," In Positive Psychology in Practice: Promoting Human Flourishing in Work, Health, Education and Everyday Life, 2015.

[48] W. Xu, T. Oei, X. Liu, X. Wang, et al., "The moderating and mediating roles of self-acceptance and tolerance to others in the relationship between mindfulness and subjective well-being," Journal of Health Psychology, vol. 21, no. 7, pp. 1446-1456, 2014, doi: https://doi.org/10.1177/1359105314555170.

[49] H. Sua, L. Wang, Y. Lia, et al., "The mediating and moderating roles of self-acceptance and self-reported health in the relationship between self-worth and subjective well-being among elderly Chinese rural empty-nester: An observational study," Quality Improvement Study, vol. 98, no. 28, pp. 1-7, 2019, doi: https://doi.org/10.1097/MD.0000000000016149.

[50] S. Sarwono, “Adolescent Psychology [in Indonesian]," Grafindo Persada, 2011.

[51] F. Nayana, "Family functioning and subjective well-being in adolescents [in Indonesian]," Jurnal Ilmiah Psikologi Terapan, vol. 1, no. 2, pp. 230-244, 2013.

[52] A. Eryilmaz, "Investigation of the relations between religious activities and subjective well-being of high school students," Educational Sciences: Theory and Practice, vol. 15, no. 2, pp. 433-444, 2015, doi: https://doi.org/10.12738/estp.2015.2.2327.

[53] P. Watkins, R. Emmons, M. Greaves, and J. Bell, "Joy is a distinct positive emotion: Assessment of joy and relationship to gratitude and well-being," The Journal of Positive Psychology, vol. 13, no. 5, pp. 522-539, 2018, doi: https://doi.org/10.1080/17439760.2017.1414298.

[54] S. Carson and E. Langer, "Mindfulness and self-acceptance," Journal of Rational-Emotive and Cognitive-Behavior Therapy, vol. 24, no. 1, pp. 29-43, 2006, doi: https://doi.org/10.1007/s10942-006-0022-5.

[55] J. Hair, M. Sarstedt, L. Hopkins, and V. Kuppelwieser, "Partial least squares structural equation modeling (PLSSEM)," European Business Review, vol. 26, no. 2, pp. 106-121, 2014, doi: https://doi.org/10.1108/EBR-10-2013-0128.

[56] J. Hair, G. Hult, C. Ringle, and M. Sarstedt, "A Primer on Partial Least Squares Structural Equation Modeling (PLS-SEM)," Sage Publications, 2016.

[57] I. Ghozali, and H. Latan, "Partial Least Squares, Concepts, Techniques and Applications Using the Smartpls 3.0 Program for Empirical Research [in Indonesian],” Semarang: UNDIP, 2015.

[58] H. Jogiyanto, "The Concept and Application of Variance-Based Structural Equation Modeling in Business Research [in Indonesian]," UPP STIM YKPN, 2011.

[59] L. Dewi, F. Tentama, and A. Diponegoro, "Analysis of validity and reliability of the subjective well-being scale," American Research Journal of Humanities Social Science, vol. 3, no. 6, pp. 122-131, 2020.

[60] P. Muhopilah, F. Tentama, and Y. Yuzarion, "Bullying scale: A psychometric study for bullying perpetrators in junior high school," European Journal of Education Studies, vol. 7, no. 7, pp. 92-106, 2020, doi: https://doi.org/10.46827/ejes.v7i7.3158.

[61] M. Davern, R. Cummins, and M. Stokes, "Subjective wellbeing as an affective-cognitive construct," Journal of Happiness Studies, vol. 8, no. 4, pp. 429-449, 2007, doi: https://doi.org/10.1007/s10902-007-9066-1.

[62] W. Liu, J. Mei, L. Tian, and E. Huebner, "Age and gender differences in the relation between school-related social support and subjective well-being in school among students," Social Indicators Research, vol. 125, no. 3, pp. 1065-1083, 2016, doi: https://doi.org/10.1007/s11205-015-0873-1.

[63] A. Tomyn, J. Norrish, and R. Cummins, "The subjective wellbeing of indigenous Australian adolescents: validating the personal wellbeing index-school children," Social Indicators Research, vol. 110, no. 3, pp. 1013-1031, 2013, doi: https://doi.org/10.1007/s11205-010-9668-6.

[64] F. He, R. Cao, Z. Feng, et al., "The impacts of dispositional optimism and psychological resilience on the subjective well-being of burn patients: A structural equation modelling analysis," PloS One, vol. 8, no. 12, pp. 1-5, 2013, doi: https://doi.org/10.1371/journal.pone.0082939.

[65] J. Peng, X. Jiang, J. Zhang, et al., "The impact of psychological capital on job burnout of Chinese nurses: The mediator role of organizational commitment," PloS One, vol. 8, no. 12, pp. 1-7, 2013, https://doi.org/10.1371/journal.pone.0084193.

[66] K. Siewert, K. Antoniw, T. Kubiak, and H. Weber, "The more the better? The relationship between mismatches in social support and subjective well-being in daily life," Journal of Health Psychology, vol. 16, no. 4, pp. 621-631, 2011, doi: https://doi.org/10.1177/1359105310385366.

[67] R. Long, E. Huebner, D. Wedell, and K. Hills, "Measuring school-related subjective well-being in adolescents," American Journal of Orthopsychiatry, vol. 82, no. 1, pp. 50-60, 2012, doi: https://doi.org/10.1111/j.19390025.2011.01130.x.

[68] L. Tian, B. Liu, S. Huang, and E. Huebner, "Perceived social support and school well-being among Chinese early and middle adolescents: The mediational role of self-esteem," Social Indicators Research, vol. 113, no. 3, pp. 991-1008, 2013, doi: https://doi.org/10.1007/s11205-012-0123-8.

[69] L. Tian, Q. Tian, and E. Huebner, "School-related social support and adolescents' school-related subjective wellbeing: The mediating role of basic psychological needs satisfaction at school," Social Indicators Research, vol. 128, no. 1, pp. 105-129, 2016, doi: https://doi.org/10.1007/s11205-015-1021-7. 
[70] L. Tian, D. Wang, and E. Huebner, "Development and validation of the brief adolescents' subjective well-being in school scale, no. BASWBSS)," Social Indicators Research, vol. 120, no. 2, pp. 615-634, 2015, doi: https://doi.org/10.1007/s11205-014-0603-0.

[71] L. Tian, L. Zhang, E. Huebner, et al., "The longitudinal relationship between school belonging and subjective wellbeing in school among elementary school students," Applied Research in Quality of Life, vol. 11, no. 4, pp. 12691285, 2016, doi: https://doi.org/10.1007/s11482-015-9436-5.

[72] T. Peterson, L. Chatters, R. Taylor, et al., "Subjective well-being of older African Americans with DSM IV psychiatric disorders," Journal of Happiness Studies, vol. 15, no. 5, pp. 1179-1196, 2014, doi: https://doi.org/10.1007/s10902-013-9470-7.

[73] A. Yamaguchi and M. Kim, "Effects of self-construal and its relationship with subjective well-being across cultures," Journal of Health Psychology, vol. 20, no. 1, pp. 13-26, 2015, doi: https://doi.org/10.1177/1359105313496448.

[74] H. Boucher and T. English, "The Yin-Yang of personality: Implications of naïve dialecticism for social cognition, the self-concept, and well-being," In the Praeger Handbook of Personality Across Cultures, A. Church, Ed. Washington: Praeger, pp. 179-206, 2017.

[75] B. Bajaj, R. Gupta, and N. Pande, "Self-esteem mediates the relationship between mindfulness and well-being," Personality and Individual Differences, vol. 94, pp. 96-100, 2016, doi: https://doi.org/10.1016/j.paid.2016.01.020.

[76] C. Lin, "The roles of social support and coping style in the relationship between gratitude and well-being," Personality and Individual Differences, vol. 89, pp. 13-18, 2016, doi: https://doi.org/10.1016/j.paid.2015.09.032.

[77] H. Boucher, "Social class and self-concept consistency: Implications for subjective well-being and felt authenticity," Self and Identity, pp. 1-17, 2020, doi: https://doi.org/10.1080/15298868.2020.1726443.

[78] J. Zhang, D. Miao, Y. Sun, et al., "The impacts of attributional styles and dispositional optimism on subject wellbeing: A structural equation modelling analysis," Social Indicators Research, vol. 119, no. 2, pp. 757-769, 2014, doi: https://doi.org/10.1007/s11205-013-0520-7.

[79] B. Bajaj and N. Pande, "Mediating role of resilience in the impact of mindfulness on life satisfaction and affect as indices of subjective well-being," Personality and Individual Differences, vol. 93, pp. 63-67, 2016, doi: https://doi.org/10.1016/j.paid.2015.09.005.

[80] N. Sánchez-Âlvarez, N. Extremera, and P. Fernández-Berrocal, "The influence of trait meta-mood on subjective well-being in high school students: A random intercept cross-lagged panel analysis," Educational Psychology, vol. 39, no. 3, pp. 332-352, 2019, doi: https://doi.org/10.1080/01443410.2018.1543854.

[81] S. Agarwal, P. Garg, and R. Rastogi, "Testing the reciprocal relationship between quality of work life and subjective well-being: A path analysis model," International Journal of Project Organisation and Management, vol. 11, no. 2, pp. 140-153, 2019, doi: https://doi.org/10.1504/IJPOM.2019.10022103.

[82] H. Wang, C. Xu, and X. Fan, "Effect of marital relationship on women's quality of life: Testing the mediating role of subjective well-being," Journal of Community Psychology, pp. 1-12, 2018, doi: https://doi.org/10.1002/jcop.22123.

[83] S. Savahl, C. Montserrat, F. Casas, et al., "Children's experiences of bullying victimization and the influence on their subjective well-being: A multinational comparison," Child Development, vol. 90, no. 2, pp. 414-431, 2018, doi: https://doi.org/10.1111/cdev.13135.

[84] L. Pi, Y, Lin, C. Chen, J. Chiu, and Y. Chen, "Serious leisure, motivation to volunteer and subjective well-being of volunteers in recreational events," Social Indicators Research, vol. 119, no. 3, pp. 1485-1494, 2014, doi: https://doi.org/10.1007/s11205-013-0562-x.

[85] D. Brannan, R. Biswas-Diener, C. Mohr, et al., "Friends and family: A cross-cultural investigation of social support and subjective well-being among college students," The Journal of Positive Psychology, vol. 8, no. 1, pp. 65-75, 2013, doi: https://doi.org/10.1080/17439760.2012.743573.

[86] F. Annor, "Work-family enrichment among Ghanaian employees: The mediating role between social support and subjective well-being," Applied Research in Quality of Life, vol. 11, no. 4, pp. 1155-1171, 2016, doi: https://doi.org/10.1007/s11482-015-9427-6.

[87] B. Schnettler, M. Denegri, H. Miranda, et al., "Family support and subjective well-being: An exploratory study of university students in southern Chile," Social Indicators Research, vol. 122, no. 3, pp. 833-864, 2015, doi: https://doi.org/10.1007/s11205-014-0718-3.

[88] T. Matsuda, A. Tsuda, E. Kim, and K. Deng, "Association between perceived social support and subjective wellbeing among Japanese, Chinese, and Korean college students," Psychology, vol. 5, no. 6, pp. 491-499, 2014, doi: https://doi.org/10.4236/psych.2014.56059.

[89] M. Pinquart and S. Sörensen, "Influences of socioeconomic status, social network, and competence on subjective well-being in later life: A meta-analysis," Psychology and Aging, vol. 15, no. 2, pp. 187-224, 2000, doi: https://doi.org/10.1037/0882-7974.15.2.187.

[90] Q. Tian, "Intergeneration social support affects the subjective well-being of the elderly: Mediator roles of selfesteem and loneliness," Journal of Health Psychology, vol. 21, no. 6, pp. 1137-1144, 2016, doi: https://doi.org/10.1177/1359105314547245.

[91] S. Lamborn, J. Nguyen, and J. Bocanegra, "Hmong American adolescents' perceptions of mothers' parenting practices: Support, authority, and intergenerational agreement," Asian American Journal of Psychology, vol. 4, no. 1, pp. 50-60, 2013. https://doi.org/10.1037/a0031045.

[92] C. Lewis, L. Annett, S. Davenport, et al., "Mood changes following social dance sessions in people with Parkinson's disease," Journal of Health Psychology, vol. 21, no. 4, pp. 483-492, 2016. 
[93] W. Cheng, W. Ickes, and L. Verhofstadt, "How is family support related to students' GPA scores? A longitudinal study," Higher Education, vol. 64, no. 3, pp. 399-420, 2012, doi: https://doi.org/10.1007/s10734-011-9501-4.

[94] A. Danielsen, O. Samdal, J. Hetland, and B. Wold, "School-related social support and students' perceived life satisfaction," The Journal of Educational Research, vol. 102, no. 4, pp. 303-320, 2009, doi: https://doi.org/10.3200/joer.102.4.303-320.

[95] C. Malecki and M. Demaray, "Social support as a buffer in the relationship between socioeconomic status and academic performance," School Psychology Quarterly, vol. 21, no. 4, pp. 375-395, 2006. https://doi.org/10.1037/h0084129.

[96] C. Malecki, M. Demaray, S. Elliott, and P. Nolten, "The Child and Adolescent Social Support Scale," DeKalb: Northern Illinois University, 2000.

[97] L. Jiang, E. Huebner, and J. Siddall, "A short-term longitudinal investigation of school satisfaction in middle school students," Social Indicators Research, vol. 114, pp. 1073-1086, 2013, doi: https://doi.org/10.1007/s11205-012-0190-x.

[98] S. Suldo and E. Huebner, "Is extremely high life satisfaction during adolescence advantageous?," Social Indicators Research, vol. 78, no. 2, pp. 179-203, 2006, doi: https://doi.org/10.1007/s11205-005-8208-2.

[99] S. Suldo and E. Shaffer, "Looking beyond psychopathology: The dual-factor model of mental health in youth," School Psychology Review, vol. 37, no. 1, pp. 52-68, 2008, doi: https://doi.org/10.1080/02796015.2008.12087908.

[100] S. Suldo, E. Shaffer, and K. Riley, "A social-cognitive-behavioral model of academic predictors of adolescents' life satisfaction," School Psychology Quarterly, vol. 23, no. 1, pp. 56-69, 2008, doi: https://doi.org/10.1037/10453830.23.1.56.

[101] S. Cantin, and M. Boivin, "Change and stability in children's social network and self-perceptions during transition from elementary to junior high school," International Journal of Behavioral Development, vol. 28, no. 6, pp. 561-570, 2004, doi: https://doi.org/10.1080/01650250444000289.

[102] A. Nickerson and R. Nagle, "The influence of parent and peer attachments on life satisfaction in middle childhood and early adolescence," In Social Indicators Research, vol. 66, no. 1, pp. 35-60, 2004, doi: 10.1023/B:SOCI.0000007496.42095.2c.

[103] T. Stewart, and S. Suldo, "Relationships between social support sources and early adolescents' mental health: The moderating effect of student achievement level," Psychology in the Schools, vol. 48, no. 10, pp. 1016-1033, 2011, doi: https://doi.org/10.1002/pits.20607.

[104] M. McCullough, R. Emmons, and J. Tsang, "The grateful disposition: A conceptual and empirical topography," Journal of Personality and Social Psychology, vol. 82, no. 1, pp. 112-127, 2002, doi: https://doi.org/10.1037/00223514.82.1.112.

[105] A. Wood, S. Joseph, and P. Linley, "Coping style as a psychological resource of grateful people,” Journal of Social and Clinical Psychology, vol. 26, no. 9, pp. 1076-1093, 2007, doi: https://doi.org/10.1521/jscp.2007.26.9.1076.

[106] R. Emmons and C. Crumpler, "Gratitude as a human strength: Appraising the evidence," Journal of Social and Clinical Psychology, vol. 19, no. 1, pp. 56-69, 2000, doi: https://doi.org/10.1521/jscp.2000.19.1.56.

[107] S. Gable and J. Haidt, "What (and why) is positive psychology?," Review of General Psychology, vol. 9, no. 2, pp. 103-110, 2005, doi: https://doi.org/10.1037/1089-2680.9.2.103.

[108] P. Linley, S. Joseph, S. Harrington, and A. Wood, "Positive psychology: Past, present, and (possible) future," The Journal of Positive Psychology, 1, no. 1, pp. 3-16, 2006, doi: https://doi.org/10.1080/17439760500372796.

[109] G. Bono, R. Emmons, and M. McCullough, "Gratitude in practice and the practice of gratitude," Eds. John Wiley and Sons Inc, pp. 464-481, 2004.

[110] A. Duckworth, T. Steen, and M. Seligman, "Positive psychology in clinical practice," Annual Review of Clinical Psychology, vol. 1, no. 1, pp. 629-651, 2005, doi: https://doi.org/10.1146/annurev.clinpsy.1.102803.144154.

[111] R. Emmons and M. Mc Cullough, "Counting blessings versus burdens: An experimental investigation of gratitude and subjective well-being in daily life," Journal of Personality and Social Psychology, vol. 84, no. 2, pp. 377-389, 2003.

[112] P. Linley, S. Joseph, J. Maltby, et al., "Positive psychology applications," Eds. Oxford University Press, pp. 35-47, 2009, doi: https://doi.org/10.1093/oxfordhb/9780195335446.001.0001.

[113] M. Seligman, T. Rashid, and A. Parks, "Positive psychotherapy," American Psychologist, vol. 61, no. 8, pp. 774-788, 2006, doi: https://doi.org/10.1037/0003-066X.61.8.774.

[114] A. Wood and S. Joseph, "The absence of positive psychological (eudemonic) well-being as a risk factor for depression: A ten year cohort study," Journal of Affective Disorders, vol. 122, no. 3, pp. 213-217, 2010, doi: https://doi.org/10.1016/j.jad.2009.06.032.

[115] A. Wood, J. Maltby, N. Stewart, et al., "A social-cognitive model of trait and state levels of gratitude," Emotion, vol. 8, no. 2, pp. 281-290, 2008, doi: https://doi.org/10.1037/1528-3542.8.2.281.

[116] M. McCullough, S. Kilpatrick, R. Emmons, and D. Larson, "Is gratitude a moral affect?," Psychological Bulletin, vol. 127, no. 2, pp. 249-266, 2001, doi: https://doi.org/10.1037/0033-2909.127.2.249.

[117] C. Carver, M. Scheier, and S. Segerstrom, “Optimism," Clinical Psychology Review, vol. 30, no. 7, pp. 879-889, 2010, doi: https://doi.org/10.1016/j.cpr.2010.01.006.

[118] M. McCullough, J. Tsang, and R. Emmons, "Gratitude in intermediate affective terrain: Links of grateful moods to individual differences and daily emotional experience," Journal of Personality and Social Psychology, vol. 86, no. 2, pp. 295-309, 2004, doi: https://doi.org/10.1037/0022-3514.86.2.295.

[119] M. McCullough, M. Kimeldorf, M. B., and A. Cohen, "An adaptation for altruism? The social causes, social effects, and social evolution of gratitude," Current Directions in Psychological Science, vol. 17, no. 4, pp. 281-285, 2008, doi: https://doi.org/10.1111/j.1467-8721.2008.00590.x. 
[120] A. Wood, S. Joseph, J. Lloyd, et al., "Gratitude influences sleep through the mechanism of pre-sleep cognitions," Journal of Psychosomatic Research, vol. 66, no. 1, pp. 43-48, 2009, doi: https://doi.org/10.1016/j.jpsychores.2008.09.002.

[121] A. Geraghty, A. Wood, and M. Hyland, "Attrition from self-directed interventions: Investigating the relationship between psychological predictors, intervention content and dropout from a body dissatisfaction intervention," Social Science \& Medicine, vol. 71, no. 1, pp. 30-37, 2010, doi: https://doi.org/10.1016/j.socscimed.2010.03.007.

[122] A. Wood, S. Joseph, and J. Maltby, "Gratitude uniquely predicts satisfaction with life: Incremental validity above the domains and facets of the five factor model," Personality and Individual Differences, vol. 45, no. 1, pp. 49-54, 2008, doi: https://doi.org/10.1016/j.paid.2008.02.019.

[123] S. Joseph and A. Wood, "Assessment of positive functioning in clinical psychology: Theoretical and practical issues," Clinical Psychology Review, vol. 30, no. 7, pp. 830-838, 2010, doi: https://doi.org/10.1016/j.cpr.2010.01.002.

[124] A. Wood, P. Linley, J. Maltby, M. Baliousis, and S. Joseph, "The authentic personality: A theoretical and empirical conceptualization and the development of the Authenticity Scale," Journal of Counseling Psychology, vol. 55, no. 3, pp. 385-399, 2008, doi: https://doi.org/10.1037/0022-0167.55.3.385.

[125] A. Wood, J. Maltby, R. Gillett, P. Linley, and S. Joseph, "The role of gratitude in the development of social support, stress, and depression: Two longitudinal studies," Journal of Research in Personality, vol. 42, no. 4, pp. 854-871, 2008, doi: https://doi.org/10.1016/j.jrp.2007.11.003.

[126] A. Wood, S. Joseph, and J. Maltby, "Gratitude predicts psychological well-being above the Big Five facets," Personality and Individual Differences, vol. 46, no. 4, pp. 443-447, 2009, doi: https://doi.org/10.1016/j.paid.2008.11.012.

[127] A. Wood, P. Taylor, and S. Joseph, "Does the CES-D measure a continuum from depression to happiness? Comparing substantive and artifactual models," Psychiatry Research, vol. 177, no. 1-2, pp. 120-123, 2010, doi: https://doi.org/10.1016/j.psychres.2010.02.003.

[128] K. Brown and R. Ryan, "The benefits of being present: Mindfulness and its role in psychological well-being," Journal of Personality and Social Psychology, vol. 84, no. 4, pp. 822-848, 2003, doi: https://doi.org/10.1037/00223514.84.4.822.

[129] C. Collard, N. Avny, and I. Boniwell, "Teaching Mindfulness Based Cognitive Therapy (MBCT) to students: The effects of MBCT on the levels of mindfulness and subjective well-being," Counselling Psychology Quarterly, vol. 21, no. 4, pp. 323-336, 2008, doi: https://doi.org/10.1080/09515070802602112.

[130] N. Schutte, and J. Malouff, "Emotional intelligence mediates the relationship between mindfulness and subjective well-being," Personality and Individual Differences, vol. 50, no. 7, pp. 1116-1119, 2011, doi: https://doi.org/10.1016/j.paid.2011.01.037.

[131] S. Jimenez, B. Niles, and C. Park, "A mindfulness model of affect regulation and depressive symptoms: Positive emotions, mood regulation expectancies, and self-acceptance as regulatory mechanisms," Personality and Individual Differences, vol. 49, no. 6, pp. 645-650, 2010, doi: https://doi.org/10.1016/j.paid.2010.05.041.

[132] C. Ryff and B. Singer, "Psychological well-being: Meaning, measurement, and implications for psychotherapy research," Psychotherapy and Psychosomatics, vol. 65, no. 1, pp. 14-23, 1996, doi: https://doi.org/10.1159/000289026.

[133] B. Thompson and J. Waltz, "Mindfulness, self-esteem, and unconditional self-acceptance," Journal of RationalEmotive and Cognitive-Behavior Therapy, vol. 26, no. 2, pp. 119-126, 2008, doi: https://doi.org/10.1007/s10942007-0059-0.

[134] R. Hoffman, "How is gender self-confidence related to subjective well-being?," The Journal of Humanistic Counseling, Education and Development, vol. 45, no. 2, pp. 186-197, 2006, doi: https://doi.org/10.1002/j.21611939.2006.tb00017.x.

[135] P. Sanjuán, "Affect balance as mediating variable between effective psychological functioning and satisfaction with life," Journal of Happiness Studies, vol. 12, no. 3, pp. 373-384, 2011.

[136] D. Garcia, "Adolescents' happiness: The role of the affective temperament model on memory and apprehension of events, subjective well-being, and psychological well-being," Thesis, University of Gothenburg, Gothenburg, 2011.

[137] D. Garcia, "The affective temperaments: Differences between adolescents in the big five model, and cloninger's psychobiological model of personality," Journal of Happiness Studies, vol. 13, pp. 999-1017, 2012, doi: https://doi.org/10.1007/s10902-011-9303-5.

[138] J. Santrock, “Adolescence,” McGraw-Hill, 2010.

[139] K. Teodorczuk, T. Guse, and G. Du Plessis, "The effect of positive psychology interventions on hope and wellbeing of adolescents living in a child and youth care centre," British Journal of Guidance and Counselling, vol. 47, no. 2, pp. 234-245, 2019, doi: https://doi.org/10.1080/03069885.2018.1504880.

[140] E. Sari and W. Dahlia, "Family functioning and subjective well-being among adolescents," Malaysia Online Journal of Psychology and Counselling, vol. 5, no. 1, pp. 43-51, 2018.

[141] D. Garcia and T. Archer, "Adolescent life satisfaction and well-being," Journal of Alternative Medicine Research, vol. 4, no. 3, pp. 271-279, 2012.

[142] D. Garcia and A. Siddiqui, "Adolescents' psychological well-being and memory for life events: Influences on life satisfaction with respect to temperamental dispositions," Journal of Happiness Studies, vol. 10, no. 4, pp. 407-419, 2009, doi: https://doi.org/10.1007/s10902-008-9096-3. 